\title{
Globalization and its impact on Pakistan's Muslim Society
}

Hafiz Waqas Khan*

\begin{abstract}
According to Islamic thoughts, Islam has brought up the matter of globalization, the establishment of global society and global government which is accepted all over the world without any discrimination of religion and civilization. Therefore, it is said that globalization is neither good nor bad despite the whole counter agreements. It either can or cannot be desirable, but the characteristics of globalization are different from the current feature of the Islamic perspective. In the current scenario, globalization is a powerful manifestation of Western civilization supremacy. In Pakistan, we are facing complex global challenges in the family system. Islam promotes family values, which are the necessary for family bonding. Whenever the cohesive bond gets weak, society begins to tumble. We are living in a fast-pacing, hectic community, where the protection of Islamic values in Pakistani society is a challenging task. This study will provide a balance solution regarding globalization for Pakistani Muslim society. The study will suggest the legal and ethical mechanism that needs to be developed in the Pakistani Muslim Society for protecting against globalization. This study is only limited to Pakistani Muslim society.
\end{abstract}

Keywords: Globalization, Pakistani Muslim Society, Civilization, Family System

\section{Introduction}

The revolutions of the current century have entirely altered the world scenario and even in recent years, the speed of the revolutions has been such that today the world is much different from the last decade's world. Due to revolutionary change, the world has become ever smaller within one century, therefore, it is

\footnotetext{
${ }^{*}$ Hafiz Waqas Khan Sr Lecturer, Faculty of Social Sciences, Riphah International University, Islamabad - Pakistan. waqas.khan@ riphah.edu.pk
} 
said that Information technology, Transport, and new communication tools have made the world a global village.

\section{Globalization and its basis}

According to Merriam-Webster "the state of being globalized; especially: the development of an increasingly integrated global economy marked especially by free trade, free flow of capital, and the tapping of cheaper foreign labour markets." ${ }^{1}$

Anthony Giddens defined Globalization in his paper "The Consequences of Modernity" as "the globalization can be defined as the intensification of social relations throughout the world, linking distant localities in such a way that local happenings are formed as a result of events that occur many miles away and vice versa"2

The Swedish journalist Thomas Larsson says that globalization "is the process of the shrinking of the world, the shortening of distances, and the closeness of things. It allows the increased interaction of any person on one part of the world to someone found on the other side of the world, in order to benefit" 3

It is a historical truth that the idea of globalization is nothing new. Alexander the Great also wanted to have control all over the world. The philosophy of globalization is not new, but it has changed its manifestations over a period of time.

"There is a group of Muslim scholars who believe that globalization has brought an invasion of American culture to Muslim societies that will allow Muslims from inside and domesticate their identity."4

\section{The Islamic Concept of Globalization}

Islamic thought and culture are flexible to embrace all cultures and civilizations which exist in the world without any discrimination of nation, country, color because Islamic thought is not so far from human nature. Quranic verses explain the Islamic concept of globalization:

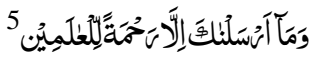

"We sent thee not, but as a Mercy for all creatures."

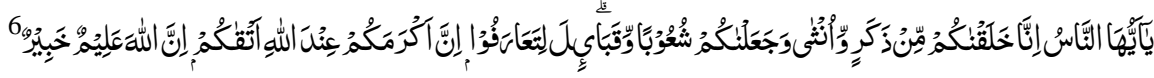


"O mankind, We have created you from a male and a female and made you into races and tribes so that you may identify one another. Surely the noblest of you, in Allah's sight, is the one who is most pious of you. Surely Allah is AllKnowing, All-Aware"

\section{7}

"O people, worship your Lord who created you and those before you, so that you may become God-fearing"

$$
8
$$

"All men used to be a single 'Ummah (i.e., on a single faith). Then (after they differed in matters of faith), Allah sent prophets carrying good news and warning..."

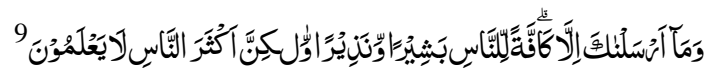

"Even if you do not find anyone in them, do not enter therein until permission is given to you. And if it is said to you, Go back', just go back; it is more decent for you. Allah is All-Aware of what you do."

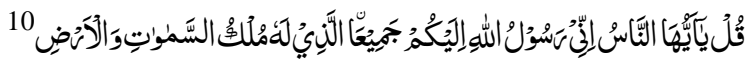

(O Prophet Muhammad) Say, :O people, I am a messenger of Allah (sent) to you from the One to whom belongs the kingdom of the heavens and the earth.

\section{Dimensions of Globalization}

Globalization is one of the leading factors of this era, which affects society in three basic areas; economy, politics and culture. Globalization is considered the most critical existing cultural phenomenon. This phenomenon has brought up many challenges in the field of culture and civilization. Pakistani Muslim society is also the victim of cultural globalization, which influences its warp and weft phenomena. This study is only limited to cultural globalization

\section{Examples of Cultural Globalization}

Western fast-food restaurants and dress brands are just found everywhere in the world. Cultural globalization is by no means a one-way highway. In Pakistan, we've adopted lots of great things from other cultures and traditions. In Europe, music from numerous countries will, despite different languages, be heard in 
restaurants and clubs. Businessmen from around the world gather in U.K., China, Japan and the U.S to share ideas about their specific field, culture, business and technology. Cultures around the world have also exchanged words or phrases. 'Ok' or the thumbs-up sign is now used everywhere thanks to Western influence. Cultural globalization includes the spread of language, arts, food, business ideas, and technology, and therefore, its impact is felt by almost everyone in the world. Ideas, values, beliefs, and merchandises are factors of cultural globalization.

\section{The cultural impact of globalization on Pakistani Muslim society}

Pakistan has a rich and unique culture that has preserved established traditions throughout 5000 years of history. Many of these cultural practices, foods, monuments, and shrines were inherited from the rule of Muslim Mughal and Afghan invaders. But now due to IT revolution, alien cultures are prevailing in Pakistani Muslim society.

\section{1-Language}

Language is the primary source to understand any one point of view. There are 54 countries where the official language is English. The national language of Pakistan is Urdu, but our education systems are based on the English language "English is considered as a language of the developed world and individuals. These situations have pushed many individuals to learn English within and outside of schools, and national-states to change their medium of instruction to English. However, it is believed that many countries have succeeded in education and economic development while educating their nationals using their local languages. According to the survey done by Organization for Economic Co-operation and Development (OECD) regarding educational achievement in 65 countries, the three countries which achieved the highest score in reading are China (Hong Kong and Shanghai regions), South Korea and Finland (OECD, 2010). All these three countries use their local languages instead of dominant foreign language (like English) as a medium of instruction in their educational institutions"11

The official language which is used in our institutions is also English. Although the Supreme Court of Pakistan ordered the government to adopt Urdu as the official language on September 08, 2015, but its implementation does not seem to materialize in Pakistani institutions except some government institutions. It 

Globalization and its impact on Pakistan's...

is said that Pakistani Muslim society is also the victim of language globalization.

\section{2- Dress}

The dress is an important aspect of any civilization and it shows the thoughts and beliefs of inhabitants. Dress of Pakistani Muslim society is going to modify with the effects of globalization. Margaret Maynard wrote his book "Dress and globalization."

In other words, we need to examine what is mean by global 'sameness' with a degree of critical attention. "One of the complicating factors is that people still exert personal choice about what they wear. This may include suits and jeans, both universal-style garments, but these are often selected and worn with quit particular aims in mind. So whilst no one would deny that there is a tendency for people worldwide to look similar to most others, even in branded gear, and the convergence of style is a major aspect of global dressing, this is complicated by many factors such as market segmentation and personal preferences"12

As fashion descriptions in magazines, films, music videos, sports, the internet, and television spread western culture up around the world, these elements create a "global fashion" across borders and cultures. Pent coat and tie, T-shirts, Blue jeans, branded perfumes, body spray, are visible everywhere in the world. Luxury shopping malls in well-off countries house all these styles under one roof. Like advanced global markets, they cater to customers of every stage, gender, civilization, profession, and subculture.

\section{3- Spend days celebrated all over the world}

Different days celebrated all over the world, which are also being celebrated in Pakistani Muslim society are also outcomes of globalization i.e. new year celebration, earth day, mother, father day, labor day, woman day etc.

Islamic ethical values emphasize the rights of every member of society during the whole year not for specific days, but facing the effects of globalization, the Pakistani Muslim society is going to link these values to only these days.

\section{4- Liberation of woman}

"Globalization promotes the theory of feminism which the theory of the political, economic, and social equality of the sexes or organized activity on behalf of women's rights and interests." "13 According to Muslim traditions, a woman is not burdened with an extra responsibility to work outside, but due to 

Globalization and its impact on Pakistan's...

globalization, the ratio of working women is increasing day by day in Pakistani Muslim society.

"The World Bank provides data for Pakistan from 1990 to 2017. The average value for Pakistan during that period was 18.43 percent with a minimum of 12.5 percent in 1995 and a maximum of 24.93 percent in 2017."14 Although in Pakistani Muslim society working women ratio is not as high as compared to other countries but it is growing over time. "Female labor force participation country data from around the world: The average for 2017 was 52.01 percent. The highest value was in Rwanda: 86.04 percent and the lowest value was in Yemen: 6 percent." 15

\section{5- Individualism}

Globalization promotes individualism rather than family relations that effects on Pakistani society. Therefore teen agers male and female both want to go to any picnic point together and no one from their family can stop them due to outbreak of individualism.

Islam as a social religion (due to its focus on group life rather than individualistic one) has shaped its own cultural identity which is meant to be upheld by Muslims. Islamic culture is characterized by a dynamic sense of moderation. It harmonizes both the material and spiritual dimensions of human personality. "It is not based on mere imitations. Islamic cultural identity is value-laden. Islamic cultural identity follows a dynamic pattern, and it is not static as it is often being misunderstood by both Muslims themselves and the secular Westerners. The major difference between the secular Western and Islamic culture is faith in one God. The Islamic faith controls the lives of its members (Muslims) in all areas of life. These areas include spiritual beliefs, lifestyle, law, and government."16

\section{6- Freedom of Expression}

Freedom of Expression is also a feature of globalization, which is effective in Pakistan's Muslim society. Due to this feature stooped attitude, intolerance, conflicts are increasing with time. According to the Universal Declaration of Human Rights (1948) "everyone has the right of freedom of opinion and expression; this right includes freedom to hold opinions without interference and to seek, receive and impart information and ideas through any media and regardless of frontiers" 17 This article of the Universal Declaration shows 

Globalization and its impact on Pakistan's...

undeclared freedom without any restrictions; that is why we can say that this article has a contradiction with Islamic thoughts.

After the U.N Adopted and opened for signature, ratification and accession by General Assembly resolution 2200A (XXI) of 16 December 1966, entry into force 23 March 1976, in accordance with Article 49 which is called International Covenant on Civil and Political Rights, According to this covenant:

1. Everyone shall have the right to hold opinions without interference.

2. Everyone shall have the right to freedom of expression; this right shall include freedom to seek, receive and impart information and ideas of all kinds, regardless of frontiers, either orally, in writing or in print, in the form of art, or through any other media of his choice.

3. The exercise of the rights provided for in paragraph 2 of this article carries with it special duties and responsibilities. It may, therefore, be subject to certain restrictions, but these shall only be such as are provided by law and are necessary:

(a) For respect of the rights or reputations of others;

(b) For the protection of national security or of public order (order public), or public health or morals. ${ }^{18}$

Despite this resolution and covenant, there are many blasphemy incidents reported just

due to Globalize philosophy of freedom of speech and expressions in Pakistani society.

On the other hand Islamic thoughts on the matter are as follows:

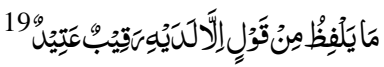

"Not a single word is uttered by one, but there is a watcher near him, ready (to record)"

Prophet Muhammad (peace be upon him) allowed his companions about freedom of speech; Battle of Badr, Uhad, Khandaq are the best examples of freedom of speech, even Prophet (peace be upon him) also taken opinion from their wives regarding contemporary issues, but Islamic education instruct that freedom of speech should be with limitations, that is big difference between Islamic thoughts and global phenomena. 


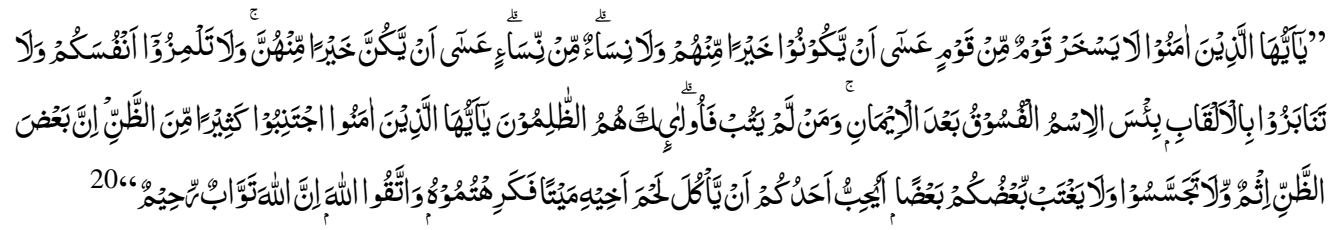

"O you who believe, no men should ever scoff at other men. May be, the latter are better than the former. Nor should women (ever scoff) at other women. May be, the latter women are better than the former ones. And do not find fault with one another, nor call one another with bad nicknames. Bad is the name of sinfulness after embracing Faith. If anyone does not repent, then such people are the wrongdoers. O you who believe, abstain from many of the suspicions. Some suspicions are sins. And do not be curious (to find out faults of others), and do not backbite one another. Does one of you like that he eats the flesh of his dead brother? You would abhor it. And fear Allah. Surely Allah is MostRelenting, Very-Merciful"

"It is our contention that the current antagonism between the Muslim world and West is in the incompatibility of Islam's fundamental values with core Western liberal values, which are rooted in secularism. One of these is the exercise of freedom of expression. "21

\section{7- Media}

Contemporary media is an outcome of new communication technology. It is also the prerequisite and facilitator for all other forms of globalization which cannot be stopped.

With the increase of globalization, the media has much power today. It has the opportunity of spreading information to places where in the past; it has been challenging to get diverse interpretations. It also can push the ideas and cultures of more leading interests. Due to media activity, one can easily get access to other civilizations. There are 45 newspapers including English, Urdu and other local languages publish in Pakistan ${ }^{22}$ and 124 TV channels. ${ }^{23}$

Social media is a global activity that also has effects on Pakistani society, therefore, "Media should show a more careful and responsible behavior; it should conduct a thorough investigation and research before filing the reports. Sensationalism should be banned to grab ratings and advertisements. To ensure this, PEMRA's code of conduct should be strictly enforced to avoid the use of free speech by media as a medium of defamation of certain individuals and 
groups. The capacity of journalists needs to be enhanced in terms of research techniques, reporting and ethical considerations." 24

\section{8- Dining out culture}

Another effect of globalization is Dining out culture, which is increasing not only in major cities but in remote areas as well. This phenomenon has increased the influence of Western Culture in Pakistan. Many Western restaurant chains have recognized and established themselves in Pakistan. Many customers consider multinational fast-food restaurants as symbols of the prosperity, development, and well-ordered openness of Western global culture and therefore become popular attractions in many cities around Pakistan, particularly among new generation with more diverse tastes.

Prof. Dr. Noor Ahmed Memon writes: "Recent statistics also demonstrate that growth in fast food in augmenting $20 \%$ annually, which implies that this is one of the fastest-growing businesses in Pakistan. Also, this signifies a hefty untapped market that can be exploited by local as well as international brands. Although Pakistan is a dawdler in technology and various other sectors, one cannot deny the exceptional growth and the potential that fast food industry inherits in Pakistan." 25

\section{9- Family system}

The family system is the main target of globalization in Pakistani Muslim society, which has almost been destroyed in western societies. Islam emphasizes to establish good relations between family members. Holy Quran says:

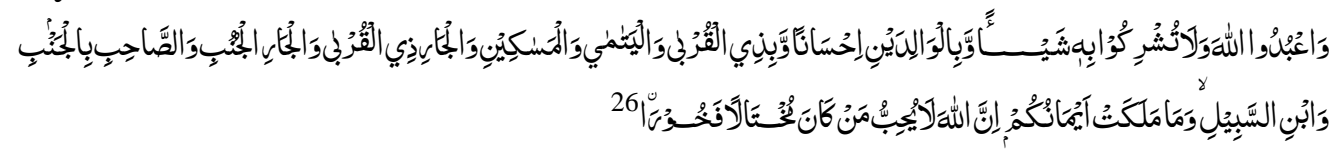

"Worship Allah, and do not associate with Him anything, and be good to parents and to kin and orphans and the needy and the close neighbor and the distant neighbor and the companion at your side and the wayfarer and to those (slaves who are) owned by you. Surely, Allah does not like those who are arrogant, proud."

That's why it is said that Islam mentions the rights of every family member individually. Anas bin Malik reported: I heard Allah's Messenger (peace be upon him) as saying: He who is desirous that his means of sustenance should 
be expanded for him or his age may be lengthened, should join the tie of relationship" 27

This hadith proves the importance of relations within a family in Muslims society. Globalization is going to change the family system in Pakistani society entirely. "Due to the influence of Modernization and Globalization, there has been definite change in the family structure and the original structure of family has been undergoing changes. The nuclear Family has become the fashion and is taking the place of joint family system. In the past, the joint family system was much prevalent in this community. But in the younger generation nuclear family system is practiced at larger scale" 28

In Pakistani Muslim society, now the joint family system is going to change to the nuclear family system. Islamic values teach "collectivism" but after globalization, this culture is now becoming an individualistic culture which exists in the west.

\section{0- Old house culture}

"Pakistan predominantly is a Muslim state where the family system is influenced by Islamic culture and Islamic values, where respect, care and sharing for each other are the basic norm. However, due to the influx of western media and other external influences we see and find western family patterns being more attractive. It is widely believed that the youngsters want to be more independent and the new married couples like to live separately and do not want to live with their parents for want of privacy." 29 According to the Holy Quran,

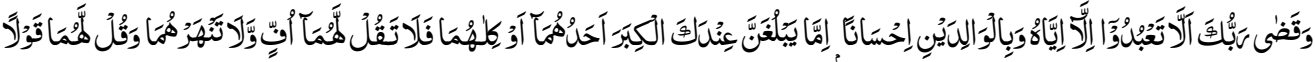

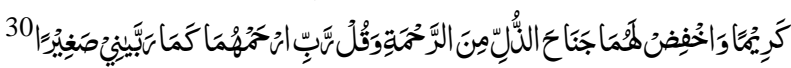

"Your Lord has decreed that you worship none but Him, and do good to parents. If anyone of them or both of them reach old age, do not say to them: uff (a word or expression of anger or contempt) and do not scold them, and address them with respectful words, and submit yourself before them in humility out of compassion, and say: My Lord, be merciful to them as they have brought me up in my childhood"

Prophet Muhammad (peace be upon him) emphasized about rights of parents in the following words:

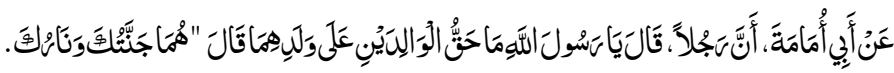


Abu Umamah narrated that a man said that: "O Allah's Messenger (peace be upon him), what are the rights of parents over their child?" He said: "They are your Paradise and your Hell.," 31

If someone is rude and impolite towards his parents, hurts them by saying abusive remarks or cause them grief or misery in any manner, then he shall find his place in Hell. "A study conducted by the Senior Citizen Welfare Trust indicates that 98 percent of the elderly population prefers to stay with their families rather than to be admitted to the old age house or somewhere else."32 "In Pakistan, the norm is to have senior citizens visit these offices in person regardless of their health or physical condition. No senior citizen counters exist at these offices, or if they do, they are non-operational. This is far from the values taught in schools: to respect, to help and to facilitate senior citizens. "When we were young, we read about how a sophisticated society acts and treats its senior citizens, but now, I realize that life is quite different from what I read in my school books," says Mrs. Nasim Dilawar, a senior citizen from Lahore. "33

\section{Conclusion}

Over the years, Pakistani Muslim society has transformed from a comparatively local to a global community. Phenomena of globalization is neither new and nor in contradiction of Islamic thought and culture. Islam wants to eliminate differences. Islam believes in universalism rather than nationalism. Globalization has the capacity to tear down the barriers created and maintained by the nation-states, but current globalization is dominated by western culture and its features show the underlying rule and control all over the world.

Globalization seems to have challenged the Muslim values and culture which affects the fabric of Pakistani Muslim society in different fields especially the Muslim family system is a specific target of globalization. In this regard, the Pakistani government, media, religious organizations and academia have a role to play to stabilize Islamic values and culture.

\section{Recommendation}

Based on my findings, I recommend that the following actions should be taken in order to address the issue of globalization in Pakistani society.

- Society should return to its origin 
- Islamic thought and culture have given a clear picture and instructions to society on how to run it.

- The family system is an essential element of any society so it should be strong according to Islamic values.

- Islamic civilization has its own identity, so we shouldn't borrow antiIslamic ways of life from any other civilizations/culture.

- Phenomena of current globalization has to be exchanged with the Islamic perspective of globalization.

- Globalization is also an opportunity to develop the glorious values and offers a ground for the achievement of global welfare as it has been given

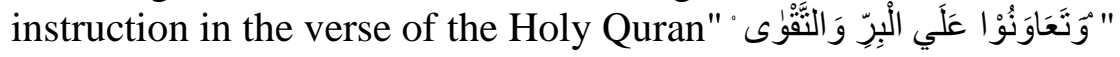

- The concept of Islamic globalization should be incorporated in our educational curriculum to prepare our students to negotiate with the western globalization on the ideological bases.

- Media should play a positive role to promote Islamic values.

- We should minimize educational and technical barriers so that the whole of humanity can prosper and get advantages of globalization.

\section{References}

${ }^{1}$ https://www.merriam-webster.com/dictionary/globalization, Accessed on Sep 24,2015

${ }^{2}$ Giddens, Anthony, The Consequences of Modernity Cambridge, Polity Press, 1991, p. 64.

${ }^{3}$ Larsson, Thomas, The Race to the Top, The Real Story of Globalization Washington, D.C, Cato Institute, 2001, p 9

${ }^{4}$ Mustafa Mohammad Tahan, Globalization and the New World Order, Hilal Publications, New Delhi: 2002, p 22

${ }^{5}$ Al-Anbia 107

${ }^{6}$ Al Hujrat 13

${ }^{7}$ Al Baqarah 21

${ }^{8}$ Al Baqarah 213

${ }^{9}$ Saba 28

${ }^{10} \mathrm{Al}$ araaf 158

11 Ashraf, Muhammad Azeem, Analysis of globalization and "Englishization" in Pakistan, International Journal of Research Studies in Language Learning 2016 January, Volume 5 Number 1, 79-88 
${ }^{12}$ Margaret Maynard, Dress and globalization, Manchester University press, 2004, p 36

${ }^{13}$ https://www.merriam-webster.com/dictionary/feminism, Accessed on Sep 22,2016

${ }^{14}$ https://www.theglobaleconomy.com/Pakistan/Female_labor_force_participa tion/, Accessed on Sep 12, 2016

${ }^{15}$ https://www.theglobaleconomy.com/rankings/Female_labor_force_participa tion/, Accessed on Aug 22, 2016

${ }^{16}$ Abu Sadat Nurullah, Globalization as a Challenge to Islamic Cultural Identity, The International Journal of Interdisciplinary Social Sciences: Annual Review, January 2008, p 18

17 Article 19, United Nations Universal Declaration of Human Rights 1948, United Nations (UN)

${ }^{18}$ Article 19, International Covenant on Civil and Political Rights, 1976

${ }^{19}$ Qaaf 18

${ }^{20}$ Al Hujrat 12

21 Muhammad Daiyabu Hassan, Islam, Globalization, and Freedom of Expression, Journal of Global Initiatives: Policy, Pedagogy, Perspective, Volume 3, p 45

${ }^{22}$ https://en.wikipedia.org/wiki/List_of_newspapers_in_Pakistan, Accessed on jan 22, 2017

23 https://en.wikipedia.org/wiki/List_of_television_channels_in_Pakistan, Accessed on jan 28, 2017

${ }^{24}$ Sadaf Liaquat, Ayesha Qaisrani, Working Paper \#159 Freedom of Expression in Pakistan: A myth or a reality, Elishma Noel Khokhar, P 17

25 Prof. Dr. Noor Ahmed Memon, (Dean KASBIT), Fast Food: 2nd largest industry in Pakistan,

${ }^{26}$ Al Nisa 36

${ }^{27}$ Sahih Muslim 2557: Book 45, The Book of Virtue, Enjoining Good Manners, and Joining of the Ties of Kinship, Hadith 23

28 Anchalesh Kumar, The impact of globalization on family-structure: a sociological study, Journal of Experimental Sciences 2012, 3(1), p 10

${ }^{29}$ Khalid Salahuddin, Dr. Amanat Ali Jalbani Senior Citizens: A Case Study of Pakistan Journal of Independent Studies and Research (JISR) Volume 4, Number 2, July 2006, p 19

${ }^{30}$ Bani Israeil 24

${ }^{31}$ Sunan Ibn Majah 3662, Book 33, Hadith 6, Vol. 5

32 Daly 2016 
${ }^{33}$ Muhammad Umer Iftikhar, Pakistan no country for old people, Dawn Published by Apr 27, 2014 